\title{
Validitas Multiplex Real Time Polymerase Chain Reaction untuk Diagnosis Limfadenitis Tuberkulosis pada Spesimen Blok Parafin
}

\author{
Mike Rezeki, ${ }^{1}$ Ida Parwati, ${ }^{2}$ Bethy S. Hernowo, ${ }^{3}$ Anna Tjandrawati ${ }^{2}$ \\ ${ }^{1}$ Instalasi Laboratorium Rumah Sakit Umum Daerah Majalengka, ${ }^{2}$ Departemen Patologi Klinik \\ Fakultas Kedokteran Universitas Padjadjaran, ${ }^{3}$ Departemen Patologi Anatomi Fakultas Kedokteran \\ Universitas Padjadjaran/Rumah Sakit Dr. Hasan Sadikin Bandung
}

\begin{abstract}
Abstrak
Limfadenitis tuberkulosis merupakan tuberkulosis ekstraparu yang paling sering ditemukan. Saat ini baku emas diagnosis limfadenitis tuberkulosis berdasarkan histopatologi. Pemeriksaan histopatologi tidak memberikan informasi etiologi pasti penyebab limfadenitis, padahal limfadenitis dapat disebabkan Mycobacterium tuberculosis maupun Mycobacterium non tuberculosis yang sangat berbeda regimen terapinya. Spesimen limfadenitis tuberkulosis dalam blok parafin yang disimpan sangat bermanfaat ketika dibutuhkan pemeriksaan lanjutan. Pemeriksaan multiplex real time polymerase chain reaction pada blok parafin dapat mendeteksi Mycobacterium tuberculosis atau Mycobacterium non tuberculosis. Pemilihan objek penelitian dilakukan berdasarkan randomisasi sederhana. Penelitian uji diagnostik dengan rancangan potong lintang untuk mengetahui validitas pemeriksaan multiplex real time polymerase chain reaction dalam mendiagnosis limfadenitis tuberkulosis sebagai konfirmasi pada blok parafin dilakukan periode Juni 2012--Juni 2013 di Rumah Sakit Dr. Hasan Sadikin Bandung. Objek penelitian terdiri atas 40 blok parafin limfadenitis tuberkulosis dan 22 blok parafin kelompok kontrol. Pemeriksaan multiplex real time poymerase chain reaction menggunakan primer gen sikuens sisipan IS6110 dan gen Mycobacterium protein tuberkulosis MPB64 untuk mendeteksi deoxyribonucleic acid Mycobacterium tuberculosis dan gen $16 S$ rRNA (ribosomal ribonucleic acid) untuk mendeteksi Mycobacterium non tuberculosis. Hasil uji validitas sensitivitas $75 \%$, spesifisitas $77 \%$, nilai duga positif $86,6 \%$, nilai duga negatif $63 \%$, dan akurasi $75,8 \%$. Pemeriksaan multiplex real time polymerase chain reaction dapat dianjurkan untuk konfirmasi diagnosis limfadenitis tuberkulosis pada blok parafin. Simpulan, multiplex real time polymerase chain reaction memiliki validitas sedang untuk diagnosis limfadenitis tuberkulosis pada spesimen blok parafin. [MKB. 2014;46(3):162-7]
\end{abstract}

Kata kunci: Deoxyribonucleic acid, limfadenitis tuberkulosis, multiplex real time polymerase chain reaction, Mycobacterium tuberculosis

\section{Validity of Multiplex Real Time Polymerase Chain Reaction for Tuberculous Lymphadenitis Diagnosis on Formalin Fixed Paraffin Embedded}

\begin{abstract}
Tuberculous lymphadenitis is the most form of extra pulmonary tuberculous. The diagnosis of tuberculous lymphadenitis based on histopathology as a gold standard. Histopathology examination could not inform the etiology lymphadenitis whether Mycobacterium tuberculous or Mycobacterium nontuberculous of which the treatment regiment is different. The multiplex real time polymerase chain reaction can detect Mycobacterium tuberculosis or Mycobacterium nontuberculosis from formalin fixed paraffin embedded. The study with cross sectional design to determine validity multiplex real time polymerase chain reaction on tuberculous lymphadenitis from formalin fixed paraffin embedded, was done June 2012-June 2013 at Dr. Hasan Sadikin General Hospital Bandung. Objects consisted of 40 formalin fixed paraffin embedded tuberculous lymphadenitis and 22 control group. The multiplex real time polymerase chain reaction use insertion sequence IS6110 and Mycobacterium protein tuberculosis MPB64 gen for detect deoxyribonucleic acid Mycobacterium tuberculosis and 16S ribosomal ribonucleic acid gen for Mycobacterium nontuberculosis. The results of validity test sensitivity $75 \%$, specificity $77 \%$, positive predictive value $86.6 \%$, negative predictive value $63 \%$, and accuracy $75.8 \%$. This examination can be used for confirmation of tuberculous lymphadenitis from formalin fixed paraffin embedded. Conclussion, the multiplex real time polymerase chain reaction gave a intermediate validity test of the diagnosis tuberculous lymphadenitis from formalin fixed paraffin embedded [MKB. 2014;46(3):162-7]
\end{abstract}

Key words: Deoxyribonucleic acid, multiplex real time polymerase chain reaction, Mycobacterium tuberculosis, tuberculous lymphadenitis

Korespondensi: Mieke Rezeki, dr., Instalasi Laboratorium Rumah Sakit Umum Daerah Majalengka, Jalan Kesehatan No 83, Majalengka 454111, mobile 08122011946,e-mail miekerejeki@yahoo.com 


\section{Pendahuluan}

Limfadenitis tuberkulosis (TB) merupakan TB ekstraparu yang paling sering ditemukan dan paling banyak terdapat pada kelenjar di daerah leher. Limfadenitis sering disebabkan oleh bakteri Mycobacterium tuberculosis dan Mycobacterium non tuberculosis (MNT) tetapi jarang dilakukan isolasi kedua jenis bakteri tersebut. Limfadenitis TB ini perlu dibedakan dari limfadenopati oleh karena penyebab lain misalnya limfadenitis yang disebabkan oleh MNT berkaitan dengan perbedaan dalam regimen terapinya. ${ }^{1}$

Insidensi limfadenitis TB sangat bervariasi, yaitu di Kanada $0,0117^{\circ}{ }_{00}^{2}$ Prevalensi limfadenitis TB di Etiopia 0,58\% ${ }_{00}{ }^{3}$ sedangkan di India pada anak $4,43 \% \%{ }^{4}$ Hasil penelitian Lestari dkk. ${ }^{5}$ tahun 2005 sampai dengan 2006 pada pasien anak di 32 rumah sakit di Pulau Jawa, Indonesia didapatkan hasil limfadenitis TB masih merupakan penyebab terbanyak TB ekstraparu (64\%) dibandingkan dengan organ lain. Jumlah limfadenitis TB di Rumah Sakit Dr. Hasan Sadikin Bandung tahun 2011 sebanyak 138 kasus dari 259 kasus TB ekstraparu. ${ }^{6}$

Konfirmasi diagnosis tersangka limfadenitis TB mempergunakan pemeriksaan bakteri tahan asam (BTA), histopatologi, atau menggunakan teknik real time polymerase chain reaction (RTPCR). Diagnosis limfadenitis TB tersebut secara histopatologi yaitu apabila ditemukan inflamasi granulomatosa dan nekrosis perkijuan. Tanpa terdapat nekrosis perkijuan diagnosis akhir hanya berdasarkan inflamasi granulomatosa. Gambaran inflamasi granulomatosa ini tidak spesifik untuk TB karena terdapat pada berbagai kondisi seperti sarkoidosis, sifilis, leprosy, penyakit Chron, reumatoid artritis, sistemik lupus eritematosus, dan pneumoconiosis. ${ }^{7}$ Pemeriksaan histopatologi dengan ditemukan inflamasi granulomatosa dan nekrosis perkijuan dipergunakan sebagai standar baku emas oleh karena memiliki sensitivitas dan spesifisitas yang tinggi bila dibandingkan dengan biakan. ${ }^{1,7,8}$

Saat ini teknik RT-PCR dipergunakan untuk mendeteksi Mycobacterium, terhadap genus dipergunakan primer $16 \mathrm{~S}$ ribosomal ribonucleic acid (rRNA), sedangkan untuk mendeteksi spesies dipergunakan primer insertion sequence (IS)6110 dan MPB64. Primer IS6110 dan MPB64 digunakan untuk membedakan $M$. tuberculosis dengan MNT. Pemeriksaan multiplex RT-PCR (M RT-PCR) merupakan alternatif pemeriksaan limfadenitis TB selain secara histopatologi, dan telah diaplikasikan untuk deteksi sikuens Mycobacterium deoxyribonucleic acid (DNA) pada berbagai bahan pemeriksaan. ${ }^{9}$ Amplifikasi asam nukleat DNA $M$. tuberculosis dengan menggunakan teknik M RT-PCR ini lebih akurat, proses amplifikasi dan juga analisisnya terjadi bersamaan sehingga waktu yang dibutuhkan untuk identifikasi DNA bakteri akan lebih singkat, dan dapat mendeteksi 1-10 basil di dalam berbagai sampel klinis. ${ }^{7}$ Tujuan penelitian untuk menilai validitas multiplex real time PCR untuk diagnosis limfadenitis TB pada blok parafin.

\section{Metode}

Pemilihan objek penelitian dilakukan berdasarkan randomisasi sederhana dari data yang terdapat dari arsip Departemen Patologi Anatomi tahun 2008-2012. Besar sampel yang ditentukan pada penelitian dihitung berdasarkan estimasi proporsi dengan mempertimbangkan nilai sensitivitas. Sebanyak 62 objek penelitian yang terdiri atas 40 blok parafin limfadenitis TB dan 22 blok parafin kelompok kontrol, diambil $5 \mu$ blok parafin dari setiap masing-msing blok parafin, dilakukan ekstraksi DNA dan pemeriksaan multiplex real time polymerase chain reaction menggunakan primer gen sikuens sisipan IS6110 dan gen Mycobacterium protein tuberculosis MPB64 untuk mendeteksi DNA $M$. tuberculosis dan gen 16S rRNA untuk mendeteksi Mycobacterium non tuberculosis. Objek penelitian blok parafin limfadenitis TB berasal dari 23 orang pasien perempuan dan 17 laki-laki, sedangkan untuk kelompok kontrol jumlah perempuan dan lakilaki adalah seimbang. Usia penderita limfadenitis terbanyak 30-40 tahun.

Penelitian ini adalah penelitian uji diagnostik dengan rancangan potong lintang yang pemilihan sampel, pemeriksaan, dan analisnya dilakukan periode Juni 2012--Juni 2013 di laboratorium Departemen Patologi Anatomi dan laboratorium Biologi Molekuler Departemen Patologi Klinik Rumah Sakit Dr. Hasan Sadikin Bandung.

\section{Hasil}

Dari 62 objek penelitian yang masuk kriteria inklusi, didapat kelompok usia terbanyak untuk limfadenitis TB adalah 30-40 tahun. Objek penelitian penderita perempuan sedikit lebih banyak bila dibandingkan dengan laki-laki yaitu $1,1: 1$.

Pada penelitian ini terdapat sebanyak 40 kasus didiagnosis sebagai limfadenitis TB secara histopatologi, setelah dilakukan pemeriksaan M RT-PCR didapatkan 30 kasus disebabkan oleh M. tuberculosis dan 10 kasus negatif, bukan disebabkan oleh M. tuberculosis maupun MNT. Hasil negatif palsu M RT-PCR pada blok parafin 
Tabel 1 Karakteristik Objek Penelitian

\begin{tabular}{|c|c|c|}
\hline Variabel & $\underset{n}{\text { Limfadenitis TB }}$ & $\begin{array}{c}\text { Kontrol } \\
\mathbf{n}\end{array}$ \\
\hline \multicolumn{3}{|l|}{ Jenis kelamin } \\
\hline Laki-laki & 17 & 11 \\
\hline Perempuan & 23 & 11 \\
\hline \multicolumn{3}{|l|}{ Usia (tahun) } \\
\hline$<10$ & 3 & 2 \\
\hline $10-<20$ & 8 & 3 \\
\hline $20-<30$ & 11 & 3 \\
\hline $30-<40$ & 12 & 4 \\
\hline $40-<50$ & 4 & 5 \\
\hline$\geq 50$ & 2 & 5 \\
\hline \multicolumn{3}{|l|}{ Letak kelenjar } \\
\hline Koli & 36 & 12 \\
\hline Aksila & 1 & 4 \\
\hline Submandibula & 0 & 1 \\
\hline Subklavikula & 3 & 0 \\
\hline Inguinal & 0 & 5 \\
\hline \multicolumn{3}{|l|}{ Usia blok parafin } \\
\hline Satu tahun & 14 & 7 \\
\hline Dua tahun & 7 & 11 \\
\hline Tiga tahun & 7 & 4 \\
\hline Empat tahun & 12 & 0 \\
\hline
\end{tabular}

Keterangan: $n=$ jumlah blok parafin

dapat disebabkan oleh berbagai faktor antara lain adalah distribusi Mycobacterium yang tidak merata pada sampel jaringan, nekrosis yang luas pada jaringan Mycobacterium, proses fiksasi dan pembuatan blok parafin serta perubahan struktur DNA sewaktu proses fiksasi formalin. Nekrosis perkijuan yang luas dapat menyebabkan hasil negatif karena Mycobacterium jarang tumbuh di bagian tengah jaringan nekrotik. Daerah nekrosis itu kekurangan oksigen yang diperlukan untuk pertumbuhan bakteri, sehingga Mycobacterium itu lebih sering berada di bagian tepi nekrosis yang masih ditemukan sel makrofag. ${ }^{10}$ Hasil negatif palsu histopatologi pada M RT-PCR dapat disebabkan oleh jumlah DNA yang kurang dari $0,2 \mu \mathrm{g}$ sehingga tidak dapat terdeteksi oleh alat. Fragmen DNA yang dapat dianalisis biasanya mempunyai bp $<500 \mathrm{bp}$, oleh karena lebih mudah berfragmentasi. Ukuran amplikon merupakan faktor yang mempunyai peran dalam keberhasilan amplifikasi, karena DNA pada blok parafin sering terdegradasi oleh prosedur fiksasi dan embedding. ${ }^{11}$

Di antara 22 blok parafin yang negatif TB

Tabel 2 Interpretasi Hasil Multiplex Real Time Polymerase Chain Reaction Mycobacterium tuberculosis

\begin{tabular}{lcccc}
\hline \multicolumn{1}{c}{ Primer } & Nilai Ct & Interpretasi & Limf. TB & Kelompok Kontrol \\
\hline $\begin{array}{l}\text { MTB } \\
\text { Mycobacteria }\end{array}$ & $<40$ & M. tuberculosis (+) & 30 & 5 \\
$\begin{array}{l}\text { MTB } \\
\text { Mycobacteria }\end{array}$ & $\geq 40$ & M. tuberculosis (-) & 10 & 17 \\
\hline
\end{tabular}

Keterangan: $\mathrm{Ct}=$ cycle treshold 
Mike Rezeki: Validitas Multiplex Real Time Polymerase Chain Reaction untuk Diagnosis Limfadenitis Tuberkulosis

Tabel 3 Validitas Pemeriksaan Multiplex RT- PCR untuk Deteksi Mycobacterium tuberculosis

\begin{tabular}{lcccc}
\hline & \multicolumn{2}{c}{ Limfadenitis TB } & \multirow{2}{*}{ Total } \\
\cline { 3 - 4 } & & Histopatologi (+) & Histopatologi (-) & \\
\hline \multirow{2}{*}{ RT- PCR } & $(+)$ & 30 & 5 & 35 \\
& $(-)$ & 10 & 17 & 27 \\
\hline
\end{tabular}

dengan pemeriksaan histopatologi, lima sampel positif dengan pemeriksaan M RT-PCR. Hal ini terjadi pada pasien dengan limfadenopati dan terdapat kecurigaan ke arah keganasan. Imunosupresi alamiah dari lesi keganasan dapat mereaktivasi infeksi TB laten. Hasil positif palsu berasal dari objek kelenjar limfe atau objek pemeriksaan yang berasal dari penderita kanker atau pasien imunokompromais.

Penelitian pemeriksaan pada blok parafin limfadenitis TB menggunakan multiplex RT-PCR memiliki angka validitas (Tabel 4).

Tabel 4 Hasil Validitas Multiplex RT-PCR

\begin{tabular}{lc}
\hline \multicolumn{1}{c}{ Parameter } & Nilai (\%) \\
\hline Sensitivitas & 75 \\
Spesifisitas & 77 \\
Nilai duga positif & 86,6 \\
Nilai duga negatif & 63 \\
Akurasi & 75,8 \\
\hline
\end{tabular}

\section{Pembahasan}

Limfadenitis sering disebabkan oleh bakteri M. tuberculosis maupun MNT. Penelitian ini merupakan penelitian yang menilai hasil validitas berupa sensitivitas, spesifisitas, nilai duga positif, nilai duga negatif, dan akurasi menggunakan teknik M RT-PCR dari sampel blok parafin limfadenitis TB. Limfadenitis TB perlu dibedakan dengan MNT karena terapinya yang sangat berbeda sehingga diperlukan suatu pemeriksaan yang dapat menentukan etiologi penyebab dengan pasti. ${ }^{1}$ Multiplex RT-PCR merupakan salah satu alat pemeriksaan yang dapat menentukan etiologi pasti penyebab limfadenitis. Limfadenitis TB sering dijumpai pada dewasa muda di negara dengan prevalensi TB yang tinggi. Infeksi $M$. tuberculosis merupakan penyebab limfadenitis yang paling sering terjadi pada anak dan dewasa. Mycobacterium tuberculosis mempunyai daya patogenitas yang lebih tinggi daripada MNT, sehingga dapat menimbulkan penyakit pada penderita dengan imunitas normal, oleh karena itu M. tuberculosis lebih sering dijumpai daripada MNT. ${ }^{10}$

Hasil negatif palsu M RT-PCR dapat disebabkan oleh jumlah kuman yang sedikit (pausibasiler) dalam jaringan. ${ }^{12}$ Jumlah DNA yang kurang dari $0,2 \mu \mathrm{g}$ dapat memberikan hasil negatif palsu karena DNA tidak dapat beramplifikasi. ${ }^{13}$ Fiksasi jaringan dengan menggunakan formalin dan disimpan dalam waktu lama dapat menyebabkan perubahan struktur dan degradasi DNA. Fiksasi yang sebaiknya digunakan untuk hasil optimal adalah penggunaan cairan neutral buffer formalin dibandingkan dengan 10\% non-buffer formalin karena akan memperlambat proses degradasi yang disebabkan oleh formalin. Penggunaan $10 \%$ non-buffer formalin dapat menyebabkan tidak teramplifikasinya DNA gen IS6110 pada real time PCR sehingga akan memberikan hasil negatif palsu. Penambahan bee wax pada parafin untuk memisahkan sampel blok parafin dapat memberikan hasil negatif palsu pada amplifikasi fragmen IS6110 M. tuberculosis. Waktu fiksasi yang baik untuk jaringan yang akan dilakukan pemeriksaan M RT-PCR adalah tidak lebih dari 24 jam untuk menghindari fiksasi berlebihan yang dapat menyebabkan crosslink dari molekul DNA. Formalin mengakibatkan terjadi kerusakan DNA ireversibel yang sering kali terjadi pada pemanjangan waktu fiksasi. Beberapa faktor yang dapat memengaruhi degradasi DNA pada blok parafin termasuk lamanya fiksasi, $\mathrm{pH}$, konsentrasi garam, dan suhu. Oksidasi non-buffer formalin membentuk asam dan lingkungan asam menyebabkan degradasi asam nukleat karena ikatan $\beta$ glikosidik pada basa purin terhidrolisis pada $\mathrm{pH} 4 .{ }^{14}$

Proses amplifikasi DNA dipengaruhi juga oleh jenis parafin dan proses penanaman jaringan di dalam parafin. Jenis parafin yang digunakan sebaiknya parafin murni tanpa campuran lilin lebah (beeswax, cerra alba). Lilin lebah umumnya ditambahkan pada parafin untuk memudahkan pemotongan sampel blok parafin. Lilin lebah ini dapat memberi hasil negatif terhadap amplifikasi fragmen gen IS6110 M. tuberculosis. Proses pencairan parafin untuk penanaman jaringan memerlukan suhu yang tinggi sehingga dapat menyebabkan proses degradasi asam nukleat. ${ }^{13}$

Target gen yang digunakan pada penelitian ini adalah fragmen DNA dari gen IS6110 dan 
MPB64 untuk mendeteksi DNA M. tuberculosis dan 16S rRNA untuk mendeteksi MNT. Sikuens fragmen DNA gen IS6110 merupakan target optimum untuk mendiagnosis $M$. tuberculosis karena keberadaannya pada hampir seluruh strain M. tuberculosis complex..$^{15}$ Penelitian Singh dkk. ${ }^{16}$ melaporkan bahwa hanya beberapa strain $M$. tuberculosis yang tidak mengandung gen IS6110 sehingga dapat mengurangi sensitivitas multiplex RT-PCR dan menyebabkan hasil negatif palsu jika hanya menggunakan gen IS6110. Gen IS6110 dan MPB64 digunakan bersama-sama untuk meningkatkan sensitivitas multiplex RTPCR. ${ }^{16}$ Kegagalan M RT-PCR untuk mendeteksi M. tuberculosis dapat juga disebabkan perbedaan primer dan probe yang digunakan. ${ }^{17}$ Kegagalan amplifikasi gen IS6110 juga dapat disebabkan karena tidak terdapatnya copy IS6110 dalam $M$. tuberculosis, walaupun M. tuberculosis yang tidak memiliki IS6110 jumlahnya sedikit. ${ }^{18}$ Jumlah base pairs yang besar dan perbedaan sikuens genom manusia dapat mengakibatkan primer tidak dapat berikatan dengan DNA kromosom sehingga memberikan hasil negatif palsu pada pemeriksaan RT-PCR. ${ }^{19}$

Penelitian ini menemukan dari 10 blok parafin limfadenitis TB dengan hasil M RT-PCR negatif, 3 (tiga) sampel memiliki nekrosis yang luas, satu sampel berasal dari penderita yang pernah mendapat terapi TB selama enam bulan, satu sampel limfadenitis mikobakterial, dan lima sampel lainnya secara histopatologi sesuai dengan diagnosis limfadenitis TB. Hasil negatif palsu M RT-PCR pada blok parafin dapat disebabkan oleh berbagai faktor antara lain terlalu sedikitnya basil dalam sampel, distribusi Mycobacterium yang tidak merata pada sampel jaringan, nekrosis yang luas pada jaringan Mycobacterium, proses fiksasi dan pembuatan blok parafin, serta perubahan struktur DNA sewaktu proses fiksasi formalin. ${ }^{7}$

Lima sampel yang positif multiplex RTPCR berasal dari satu pasien anak dengan kista ductus tiroglosus regio koli anterior, satu orang pasien dewasa dengan limfadenopati koli dan dicurigai metastasis keganasan ke area koli, satu orang pasien wanita dengan diagnosis klinis limfadenopati regio aksila sinistra dan benjolan di payudara kiri, 1 (satu) orang pasien laki-laki dengan diagnosis limfadenopati koli dekstra dan limfadenopati inguinal, serta 1 (satu) orang perempuan dengan diagnosis limfadenopati koli. Organ spesifik seperti kelenjar limfe merupakan tempat persisten untuk M. tuberculosis, karena reaktivasi dan replikasi dapat terjadi ketika daya tahan tubuh dan imunitas pejamu rendah. ${ }^{20}$ Pemeriksaan biopsi hanya menganalisis sebagian jaringan yang diambil saat biopsi eksisi sehingga distribusi dan jumlah basil yang bervariasi pada setiap bagian akan memberikan hasil negatif palsu. ${ }^{11}$

Hasil positif pun tidak selalu menunjukkan kuman yang aktif, karena kuman dorman atau persisten dapat terdeteksi dengan pemeriksaan ini. ${ }^{12}$ Hasil positif palsu M RT-PCR dapat terjadi oleh karena kontaminasi silang walaupun pada penelitian ini menggunakan tahapan PCR yang berbeda pada setiap tahapannya (ekstraksi DNA, pre-PCR mixing, PCR) dilakukan di ruangan yang berbeda untuk mengurangi kontaminasi silang. ${ }^{7}$ Kontaminasi dapat juga terjadi selama pemotongan blok parafin, walaupun setiap selesai pemotongan parafin menggunakan cairan RNase pada pisau pemotong. Kontaminasi dapat juga terjadi selama ekstraksi dan amplifikasi DNA walaupun pada penelitian ini internal control dapat berfungsi baik.

Pemeriksaan multiplex real time polymerase chain reaction dapat dianjurkan untuk konfirmasi diagnosis limfadenitis tuberkulosis pada kasus tersangka kuat limfadenitis TB secara klinis, tetapi hasil histopatologi tidak memperlihatkan limfadenitis TB. Keterbatasan pada penelitian ini adalah tidak dilakukan pengukuran konsentrasi DNA setelah ekstraksi DNA sehingga ketika dilakukan pemeriksaan M RT-PCR kemungkinan ada beberapa sampel yang memiliki konsentrasi DNA sangat rendah sehingga memberikan hasil negatif palsu.

Simpulan, multiplex real time PCR memiliki validitas yang sedang untuk diagnosis limfadenitis tuberkulosis pada spesimen blok parafin.

\section{Daftar Pustaka}

1. Derese Y, Hailu E, Assefa T, Bekele Y, Mihret A, Aseffa A, dkk. Comparison of PCR with standard culture of fine needle aspiration samples in the diagnosis of tuberculosis lympadenitis. J Infect Dev Ctries. 2012;6(1): 53-7.

2. Cook VJ, Manfreda J, Hershfield ES. Tuberculous lymphadenitis in Manitoba: incidence, clinical characteristics and treatment. Can Respir J. 2004;11(4):279-86.

3. Abebe G, Deribew A, Apers L, Abdissa A, Deribie F, Woldemichael K, dkk. Tuberculosis lymphadenitis in Southwest Ethiopia: a community based cross-sectional study. BMC Public Health. Research Support, NonU.S. Gov't. 2012;12:504.

4. Verma J, Dhavan I, Nair D, Manzoor N, Kasana D. Rapid culture diagnosis of tuberculous lymphadenitis from a tertiary care centre in an endemic nation: Potential and pitfalls. Indian J Med Microbiol. 2012; 
30(3):342-5.

5. Lestari T, Probandari A, Hurtig AK, Utarini A. High caseload of childhood tuberculosis in hospitals on Java Island, Indonesia: a cross sectional study. BMC Public Health. Multicenter Study Research Support, NonU.S. Gov't. 2011;11:784.

6. DOTS P. Laporan Triwulan Penemuan Pasien TB Poli DOTS. 2011.

7. Chawla K, Gupta S, Mukhopadhyay C, Rao PS, Bhat SS. PCR for M. tuberculosis in tissue samples. J Infect Dev Countries. 2009; $3(2): 83-7$.

8. Beyene D, Ashenafi S, Yamuah L, Aseffa A, Wiker $\mathrm{H}$, Engers $\mathrm{H}$, dkk. Diagnosis of tuberculous lymphadenitis in Ethiopia: correlation with culture, histology and HIV status. The international journal of tuberculosis and lung disease: the official journal of the International Union against Tuberculosis and Lung Disease. Comparative Study Research Support, Non-U.S. Gov't. 2008 Sep;12(9):1030-6.

9. Hillemann D, Galle J, Vollmer E, Richter E. Real-time PCR assay for improved detection of Mycobacterium tuberculosis complex in paraffin-embedded tissues. Int J Tuberc Lung Dis. 2005;10(3):340-2.

10. Grange JM. Mycobacterium. Dalam: Greenwood D, Slack R, Peutherer J, Barer M, penyunting. Medical microbiology. Toronto: Churchill Livingstone Elsevier; 2007. hlm. 206-20.

11. Barcelos D, Franco MF, Cardoso S. Effects of tissue handling and processing steps on PCR for detection of Mycobacterium tuberculosis in formalin-fixed paraffinembedded samples. Rev Inst Med Trop Sao Paulo. 2008;50(6):321-6.

12. Chakravorty S, Sen MK, Tyagi JS. Diagnosis of extrapulmonary tuberculosis by smear, culture, and pcr using universal sample processing technology. J Clin Microbiol. 2005;43(9):4357-62.

13. Schewe C, Goldmann T, Grosser M, Zink A, Schluns K, Pahl S, dkk. Inter-laboratory validation of PCR-based detection of Mycobacterium tuberculosis in formalin- fixed, paraffin-embedded tissues. Virchows Archiv : an international journal of pathology. Comparative Study Multicenter Study Validation Studies. 2005 Sep;447(3):573-85.

14. Zsikla V, Baumann M, Cathomas G. Effect of buffered formalin on amplification of DNA from paraffin wax embedded small biopsies using real-time PCR. J Clin Pathol. 2004 Jun;57(6):654-6.

15. Ghenaat J, Omidi A, Ghazvini K, Ayatollahi $\mathrm{H}$, Jafarian $\mathrm{AH}$, Erfanian $\mathrm{M}$, dkk. Comparison of multiplex PCR and acid fast and auramine-rhodamine staining for detection of Mycobacterium tuberculosis and nontuberculosis mycobacteria in paraffinembedded pleural and bronchial tissues with granulomatous inflammation and caseous necrosis. J Microbiol. 2007;4:1-9.

16. Singh HB, Singh P, Jadaun GPS, Srivastava K, Sharma VD, Chauhan DS, dkk. Simultaneous Use of Two PCR systems targeting IS6110 and MPB64 for confirmation of diagnosis of tuberculous lymphadenitis J Commun Dis. 2006;38(3):274-9.

17. Drews SJ, Eshaghi A, Pyskir D, Chedore P, Lombos E, Broukhanski G, dkk. The relative test performance characteristics of two commercial assays for the detection of Mycobacterium tuberculosis complex in paraffin-fixed human biopsy specimens. Diagnostic Pathol. 2008;3:37.

18. Menendez MdC, Samper S, Otal I, Garcia MJ. IS6110 the double-edged passenger. Dalam: Cardona P-J, penyunting. Understanding Tuberculosis - Deciphering the secret life of the bacilli. Croatia: InTech Europe; 2012. hlm. 60-88.

19. Pan XB, Wei L, Han JC, Gao Y. Cellular chromosome DNA interferes with fluorescence quantitative real-time PCR detection of HBV DNA in culture medium. J Med Virol. 2008;80(1):47-52.

20. Honore-Bouakline S, Vincensini JP, Giacuzzo V, Lagrange PH, Herrmann JL. Rapid diagnosis of extrapulmonary tuberculosis by PCR: impact of sample preparation and DNA extraction. J Clin Microbiol. 2003;41(6): 2323-9. 